\title{
Isolation of Bartonella species from rodents in Taiwan including a strain closely related to 'Bartonella rochalimae' from Rattus norvegicus

\begin{abstract}
Correspondence
Chao-Chin Chang

changcc@dragon.nchu.edu.tw
\end{abstract} \\ Received 2 July 2008 \\ Accepted 20 August 2008

\author{
Jen-Wei Lin, ${ }^{1}$ Chun-Yu Chen, ${ }^{2}$ Wan-Ching Chen, ${ }^{3}$ Bruno B. Chomel ${ }^{4}$ \\ and Chao-Chin Chang ${ }^{2}$
}

\footnotetext{
${ }^{1}$ Department of Veterinary Medicine, College of Veterinary Medicine, National Chung Hsing University, Taichung 402, Taiwan

${ }^{2}$ Graduate Institute of Veterinary Public Health, National Chung Hsing University, Taichung 402, Taiwan

${ }^{3}$ Department of Safety Health and Environmental Engineering, Central Taiwan University of Science and Technology, Taichung 406, Taiwan

${ }^{4}$ Department of Population Health and Reproduction, School of Veterinary Medicine, University of California, Davis, CA, USA
}

\begin{abstract}
An increasing number of Bartonella species originally isolated from small mammals have been identified as emerging human pathogens. During an investigation of Bartonella infection in rodent populations carried out in Taiwan in 2006, a total of 58 rodents were tested. It was determined that $10.3 \%(6 / 58)$ of the animals were Bartonella bacteraemic. After PCR/RFLP analysis, four isolates were identified as Bartonella elizabethae and one isolate as Bartonella tribocorum. However, there was one specific isolate with an unrecognized PCR/RFLP pattern. After further sequence and phylogenetic analyses of the glt $A$, fts $Z$ and rpo $B$ genes, and the 16S-23S rRNA intergenic spacer region, the results indicated that this specific isolate from Rattus norvegicus was closely related to human pathogenic 'Bartonella rochalimae'. Further studies need to be
\end{abstract} conducted to evaluate whether this rodent species could be a reservoir for ' $B$. rochalimae'.
}

\section{INTRODUCTION}

Bartonella species are short rod, fastidious, Gram-negative and oxidase-negative bacteria (Boulouis et al., 2005; Breitschwerdt \& Kordick, 2000). Since the early 1990s, more than 20 species within the genus Bartonella have been recognized (Eremeeva et al., 2007; Zeaiter et al., 2002). These intracellular bacteria are regarded as emerging zoonotic pathogens, which can cause serious diseases in humans worldwide (Boulouis et al., 2005). A new species, 'Bartonella rochalimae', was recently isolated from a case of splenomegaly in a patient who had travelled to South America (Eremeeva et al., 2007). This event raised the concern that it could be a newly emerged zoonotic pathogen. However, to date, little is known regarding to the reservoirs and vectors for the transmission of ' $B$. rochalimae'.

Small mammals are natural hosts for several Bartonella species, some of which can cause human diseases (Boulouis et al., 2005; Zeaiter et al., 2002). The order Rodentia has

Abbreviation: ITS, intergenic spacer region.

The GenBank/EMBL/DDBJ accession numbers for the glt $A$, fts $Z$ and rpo $B$ genes and the 16S-23S rRNA ITS sequence of Bartonella 1-1C strain are EU551154, EU551155, EU551156 and EU551157. been reported as the reservoir for several Bartonella species (Ellis et al., 1999) that are pathogens for humans, such as Bartonella elizabethae reported in a case of endocarditis (Daly et al., 1993). Bartonella grahamii, isolated primarily from bank voles (Clethrionomys glareolus), was identified to be the causative agent of neuroretinitis in humans (Baker, 1946; Kerkhoff et al., 1999). Although the main route of transmission for rodent Bartonella species is still unclear, these infections are likely to be vector-borne, mainly by fleas. For instance, Ctenophthalmus nobilis, collected on bank voles in the UK, was shown to be a competent vector for $B$. grahamii and Bartonella taylorii (Bown et al., 2004; Brenner et al., 1993). In Kabul, Afghanistan, B. taylorii was also detected by molecular methods in fleas collected from gerbils (Meriones libycus), and B. elizabethae and Bartonella doshiae were identified in rat fleas (Marié et al., 2006). More recently, Bartonella clarridgeiae-like bacteria were detected in rat fleas (Xenopsylla cheopis) collected from brown rats (Rattus norvegicus) from Egypt (Loftis et al., 2006). Similarly, when studying Bartonella infection in flea vectors (Polygenis gwyni) parasitizing cotton rats (Sigmodon hispidus), some samples were co-infected with a strain phylogenetically related to $B$. clarridgeiae (Abbot et al., 2007). 
Our laboratory has been collaborating with the Center for Disease Control, Taiwan, to conduct an epidemiological survey of Bartonella species in small mammals in central Taiwan. In this study, using molecular methods and sequencing various genes for the obtained isolates, our aim was to determine if a ' $B$. rochalimae'-like organism could be isolated from rodents and the prevalence of Bartonella infection in rodents in Taiwan.

\section{METHODS}

Sample collection. Between March and October 2006, a total of 58 rodents ( $53 \mathrm{R}$. norvegicus, 2 Mus musculus and 3 Rattus rattus) were captured in Taichung, a city located in central Taiwan. After being humanely anaesthetized with zoletil 50 (Virbac Laboratories), the animals were bled to death via cardiac puncture by using $3 \mathrm{ml}$ syringes fitted with 22 gauge, $3.8 \mathrm{~cm}$ needles. The blood was then collected in a tube containing $10 \mu \mathrm{l}\left(1.5 \mathrm{mg} \mathrm{m}^{-1}\right)$ EDTA, and was stored at $-80{ }^{\circ} \mathrm{C}$ for isolation and molecular identification of Bartonella species.

Blood culture for Bartonella species. For bacterial culture, $200 \mu \mathrm{l}$ thawed whole blood sample was plated onto both fresh $10 \%$ sheep blood-enriched Columbia agar and chocolate agar. The plates were incubated at $35{ }^{\circ} \mathrm{C}$ in $5 \% \mathrm{CO}_{2}$ for at least 1 month and checked for growth of Bartonella species on a weekly basis (Boulouis et al., 2005). The suspected colonies were subcultured onto a fresh agar plate for further molecular identification of Bartonella species by PCR/RFLP and sequence analyses.

DNA extraction and PCR/RFLP procedures for Bartonella species. After culturing a single colony pick from the original plate, DNA of the cultured isolates was extracted using a Viogene DNA/ RNA extraction kit (Viogene Biotek) following the manufacturer's instructions. The primers used for DNA amplification and sequencing in this study are shown in Table 1. The primers BhCS.781p and BhCS.1137n were used first for amplifying a partial fragment, ranging from 380 to $400 \mathrm{bp}$, of the gltA gene of Bartonella species. PCR mixtures were set up as follows: $5 \mu \mathrm{DNA}$ template, $0.5 \mu \mathrm{l} 100 \mu \mathrm{M}$ each primer, $4 \mu \mathrm{l} 2.5 \mathrm{mM}$ dNTPs, $5 \mu \mathrm{l} 10 \times$ PCR buffer, $3 \mu \mathrm{l} 25 \mathrm{mM}$ $\mathrm{MgCl}_{2}, 31.75 \mu \mathrm{l}$ sterile distilled $\mathrm{H}_{2} \mathrm{O}$ and $0.25 \mu \mathrm{l}$ DNA polymerase (AmpliTaq Gold; Applied Biosystems). The PCR amplification was executed as follows: 1 cycle of $10 \mathrm{~min}$ at $95{ }^{\circ} \mathrm{C}$, followed by 45 cycles of $30 \mathrm{~s}$ at $95^{\circ} \mathrm{C}, 1 \mathrm{~min}$ at $57{ }^{\circ} \mathrm{C}$ and $2 \mathrm{~min}$ at $72{ }^{\circ} \mathrm{C}$, and then $1 \mathrm{cycle}$ of $5 \mathrm{~min}$ at $72{ }^{\circ} \mathrm{C}$ for final extension (Norman et al., 1995). Primers bartsppA and bartsppB amplified a fragment of the 16S-23S rRNA intergenic spacer region (ITS) by single-step PCR (Jensen et al., 2000); the different molecular size of the PCR products allowed for quick differentiation of various Bartonella species. The PCR program for the ITS was as follows: 1 cycle of 2 min at $95{ }^{\circ} \mathrm{C}$, followed by 45 cycles of $1 \mathrm{~min}$ at $95{ }^{\circ} \mathrm{C}, 1 \mathrm{~min}$ at $52{ }^{\circ} \mathrm{C}$ and $30 \mathrm{~s}$ at $72{ }^{\circ} \mathrm{C}$, and $1 \mathrm{cycle}$ of $10 \mathrm{~min}$ at $72{ }^{\circ} \mathrm{C}$ for complete extension (Jensen et al., 2000). The primers for the amplification of the fts $Z$ gene were Bfp 1 and Bfp2. A $900 \mathrm{bp}$ fragment was expected from the amplification. The PCR program consisted of: 1 cycle of $4 \mathrm{~min}$ at $94{ }^{\circ} \mathrm{C}$, followed by 44 cycles of $30 \mathrm{~s}$ at $94{ }^{\circ} \mathrm{C}, 30 \mathrm{~s}$ at $55{ }^{\circ} \mathrm{C}$ and $1 \mathrm{~min}$ at $68{ }^{\circ} \mathrm{C}$, and then 1 cycle of $10 \mathrm{~min}$ at $68{ }^{\circ} \mathrm{C}$ for complete extension (Zeaiter et al., 2002). For PCR amplification of the $r p o B$ gene, a set of primers $1400 \mathrm{~F}$ and $2300 \mathrm{R}$ was used to amplify an expected $900 \mathrm{bp}$ DNA fragment. The PCR was performed as follows: 1 cycle of $2 \mathrm{~min}$ at $94{ }^{\circ} \mathrm{C}, 35$ cycles of $30 \mathrm{~s}$ at $94{ }^{\circ} \mathrm{C}, 30 \mathrm{~s}$ at $53{ }^{\circ} \mathrm{C}$ and $1 \mathrm{~min}$ at $72{ }^{\circ} \mathrm{C}$, and then 1 cycle of $2 \mathrm{~min}$ at $72{ }^{\circ} \mathrm{C}$ for complete extension (Renesto et al., 2001). RFLP of the gltA gene was also used for quick identification of Bartonella organisms at the species level with restriction enzyme digestion with TaqI (New England BioLabs), HhaI (New England BioLabs) and MseI (New England BioLabs) following the manufacturer's instructions. The RFLP banding patterns were then compared to the patterns of Bartonella type strains, including Bartonella alsatica (IBS382T) CIP 105477, Bartonella birtlesii (IBS 325T) CIP 106294, Bartonella bovis (91-4T) CIP 106692, B. clarridgeiae (Houston-2T) ATCC 51734, B. doshiae (R18T) NCTC 12862, B. elizabethae (F9251T) ATCC 49927, B. grahamii (V2T) NCTC 12860 b, Bartonella henselae (Houston-1T) ATCC 49882, Bartonella koehlerae (C-29T) ATCC 700693, Bartonella quintana (FullerT) ATCC VR-358, B. taylorii (M6T) NCTC 12861, Bartonella tribocorum (IBS 506T) CIP 104576, Bartonella. vinsonii subsp. arupensis (OK 94-513T) ATCC 700727, B. vinsonii subsp. berkhoffii (93-CO1T) ATCC 51672, B. vinsonii subsp. vinsonii (BakerT) ATCC VR-152.

Sequencing and phylogenetic analyses for Bartonella species. The confirmed PCR products were sent for automated sequencing using the primers listed in Table 1 (Mission Biotech). Sequences of several Bartonella species were downloaded for comparison from GenBank. The sequences of the gltA, fts $Z$ and $r p o B$ genes, and the 16S-23S rRNA ITS, of the Bartonella strain (1-1C) isolated in this study have been submitted to the GenBank. The accession numbers are EU551154 for the gltA gene, EU551155 for the ftsZ gene, EU551156 for the $r p o B$ gene and EU551157 for the 16S-23S rRNA ITS. Sequences were first aligned by the CLUSTAL $\mathrm{w}$ method of the BioEdit program (Tom Hall, Ibis Biosciences, Isis Pharmaceuticals). Phylogenetic analysis was performed on the aligned DNA sequences using maximum-parsimony as implemented in PHYLIP version 3.6 (Joseph Felsenstein, Department of Genome Sciences and Department of Biology, University of Washington, Seattle, WA,

Table 1. Primers used for PCR amplification and sequencing

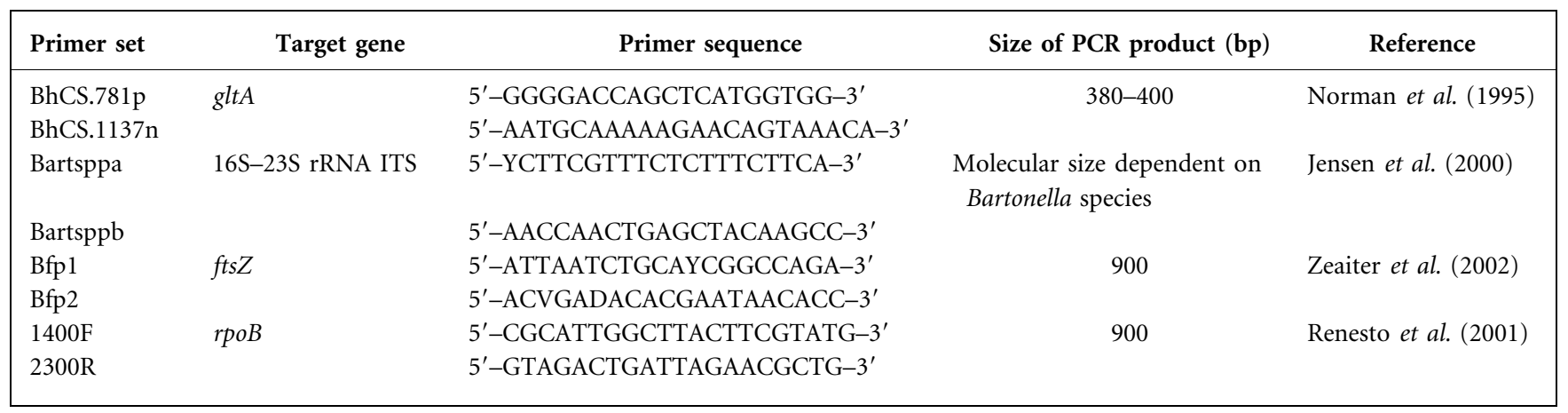


(a)

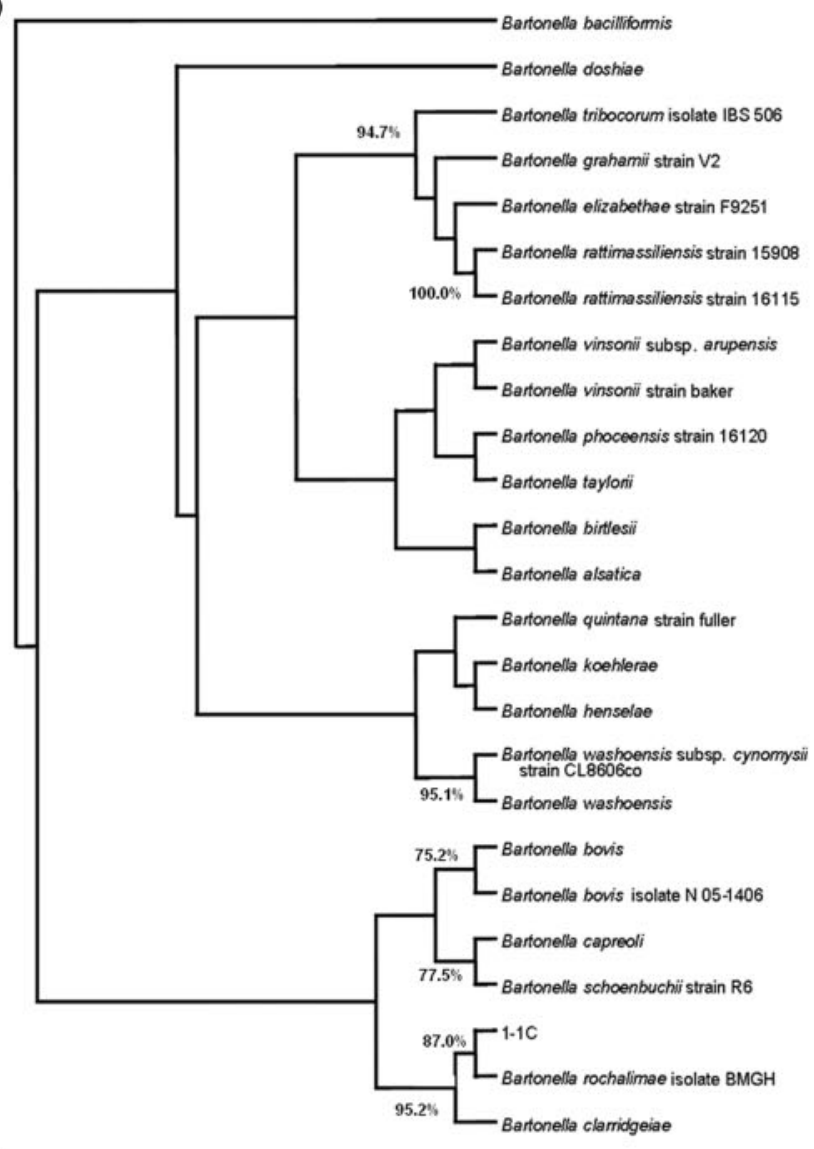

(c)

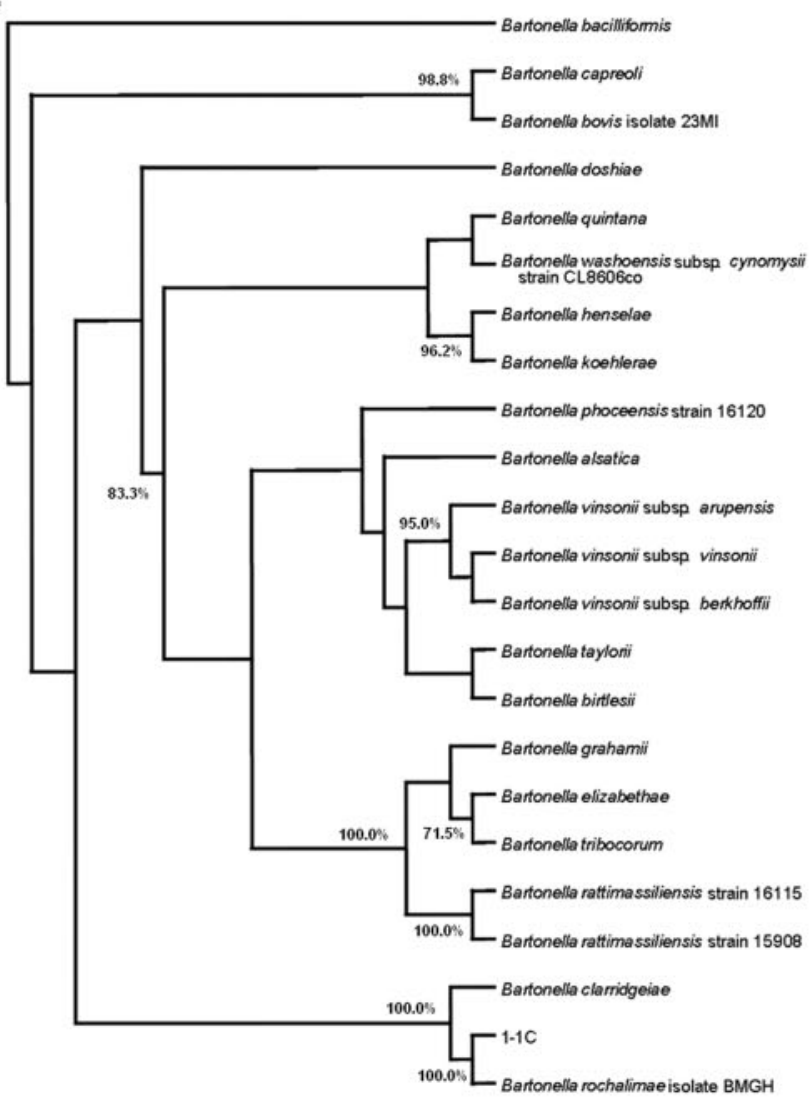

(b)

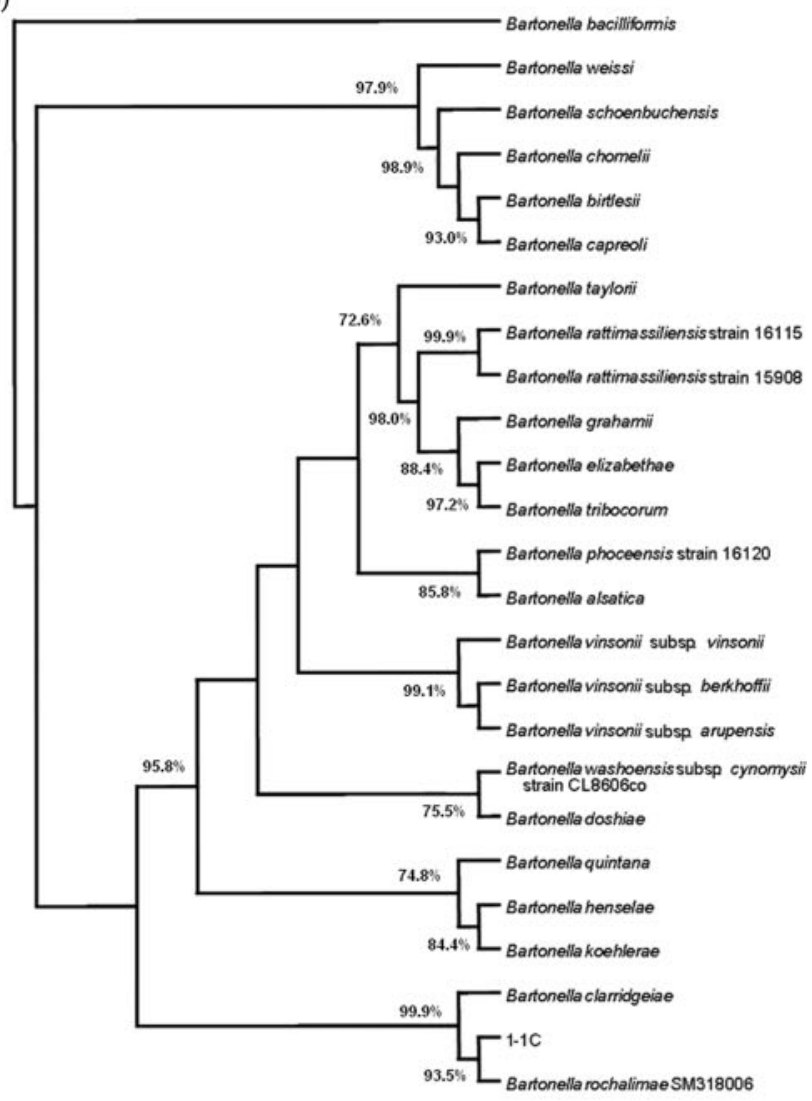

Fig. 1. Phylogenetic analysis of different Bartonella species on the basis of partial DNA sequences of: (a) the gltA gene, (b) the fts $Z$ gene and (c) the $r p o B$ gene. The phylogenetic relationship was constructed by using the maximum-parsimony method of the PHYLIP version 3.6 program, and bootstrap analysis was performed with 1000 trials of bootstrap data (bootstrap values not shown if lower than $70 \%)$. 
Table 2. Accession numbers of the reference Bartonella species sequences used for phylogenetic analysis in this study

\begin{tabular}{|c|c|c|c|}
\hline \multirow[t]{2}{*}{ Bartonella strain } & \multicolumn{3}{|c|}{ Sequence accession no. } \\
\hline & gltA & $f t s Z$ & rрoв \\
\hline B. alsatica & AF204273 & AF467763 & AF165987 \\
\hline B. bacilliformis & AF478357 & AF007266 & AF165988 \\
\hline B. birtlesii & AF204272 & AF467762 & AB196425 \\
\hline B. bovis & AF293394 & - & - \\
\hline B. bovis isolate $23 \mathrm{MI}$ & - & - & DQ356076 \\
\hline B. bovis isolate $\mathrm{N} 05-1406 \mathrm{~N} 05$ & EF432056 & - & - \\
\hline B. capreoli & AF293392 & AB290192 & AB290188 \\
\hline B. chomelii & - & AB290193 & - \\
\hline B. clarridgeiae & U84386 & AF141018 & AF165990 \\
\hline B. doshiae & AF207827 & AF467754 & AF165991 \\
\hline B. elizabethae & - & AF467760 & AF165992 \\
\hline B. elizabethae strain F9251 & Z70009 & - & - \\
\hline B. grahamii & - & AF467753 & AF165993 \\
\hline B. grahamii strain V2 & Z70016 & - & - \\
\hline B. henselae & L38987 & AF061746 & AF171071 \\
\hline B. koehlerae & AF176091 & AF467755 & AY166580 \\
\hline 'B. phoceensis' strain 16120 & AY515126 & AY515135 & AY515132 \\
\hline B. quintana & - & AF061747 & AF165994 \\
\hline B. quintana strain Fuller & Z70014 & - & - \\
\hline 'B. rattimassiliensis' strain 15908 & AY515124 & AY515133 & AY515130 \\
\hline 'B. rattimassiliensis' strain 16115 & AY515125 & AY515134 & AY515131 \\
\hline 'B. rochalimae' isolate $\mathrm{BMGH}$ & DQ683195 & - & DQ683198 \\
\hline 'B. rochalimae’ SM318006 & - & DQ676490 & - \\
\hline B. schoenbuchensis & - & AF467765 & - \\
\hline B. schoenbuchii strain R6 & AJ278186 & - & - \\
\hline B. taylorii & AF191502 & AF467756 & AF165995 \\
\hline B. tribocorum & - & AF467759 & AF165996 \\
\hline B. tribocorum isolate IBS 506 & AJ005494 & - & - \\
\hline B. vinsonii strain Baker & Z70015 & - & - \\
\hline B. vinsonii subsp. arupensis & AF214557 & AF467758 & AY166582 \\
\hline B. vinsonii subsp. berkhoffii & - & AF467764 & AF165989 \\
\hline B. vinsonii subsp. vinsonii & - & AF467757 & AF165997 \\
\hline 'B. washoensis' & AF470616 & - & - \\
\hline $\begin{array}{l}\text { B. washoensis subsp. cynomysii strain } \\
\text { CL8606co }\end{array}$ & DQ897367 & DQ825692 & DQ825688 \\
\hline 'B. weissi' & - & AF467761 & - \\
\hline
\end{tabular}

USA). Bootstrap support was calculated by using 1000 bootstrap data replicates as implemented by SEQBOOT of the PHYLIP program.

\section{RESULTS}

Using whole blood culture, $6(10.3 \%)$ of the 58 animals were Bartonella bacteraemic. Among the six bacteraemic animals, five were $R$. norvegicus and one was $R$. rattus. After PCR/RFLP analysis and pattern comparisons of Bartonella type strains, it was determined that four of the five isolates from $R$. norvegicus were B. elizabethae and the isolate from $R$. rattus was $B$. tribocorum. However, there was one specific isolate with an unrecognized PCR/RFLP pattern, which was one undigested band ( $380 \mathrm{bp}$ ) by TaqI, two bands (285 and $94 \mathrm{bp}$ ) by HhaI and two bands (199 and
$132 \mathrm{bp)}$ by MseI digestion. Therefore, this isolate was further characterized by direct DNA sequencing for species determination.

For this specific isolate, three randomly picked colonies from the original plate were subcultured and harvested for DNA extraction after 1 week. There was no gltA sequence variation between the isolates, thus a single isolate (designated 1-1C) was used for subsequent sequencing of the other genes. The accession numbers of the Bartonella reference strains used for comparison are shown in Table 2. In comparison with partial sequences of the gltA gene of Bartonella species in GenBank, the DNA similarity value of this specific isolate was highest, $95.6 \%$ with ' $B$. rochalimae', followed by B. clarridgeiae ( $95 \%)$, Bartonella schoenbuchensis (90.8\%) and 'Bartonella washoensis subsp. cynomy- 
sii strain CL8606co (90.2\%). DNA similarity was less than $90 \%$ to all other Bartonella species tested.

After sequence analysis of the fts $Z$ and $r p o B$ genes, as well as the 16S-23S rRNA ITS, the isolate 1-1C sequences were still closest to ' $B$. rochalimae' (similarity values: 97.1, 97.1 and $96 \%$, respectively). Similarly, phylogenetic analysis of the gltA, fts $Z$ and $r p o B$ genes strongly supported that isolate 1$1 \mathrm{C}$ and ' $B$. rochalimae' belonged to the same clade, as indicated by the high bootstrap value $(>90 \%)$ on the basis of 1000 replicates (Fig. 1). This clade also includes $B$. clarridgeiae and is clearly separated from other Bartonella species. When we further compared sequence relatedness between the 1-1C strain and B. clarridgeiae, we found that the similarity values were $94.3 \%$ for the $f t s Z$ gene and $93.2 \%$ for the $r p o B$ gene, and the similarity value for the $16 \mathrm{~S}-23 \mathrm{~S}$ rRNA ITS was only $69.1 \%$.

\section{DISCUSSION}

' $B$. rochalimae' has recently been isolated from a human infection (Eremeeva et al., 2007); however, the reservoir of this new human pathogen remains unknown. We report what is believed to be the first isolation of a Bartonella strain closely related to ' $B$. rochalimae' from a brown rat captured in central Taiwan. As the data are limited by the small sample size of rats tested and the lack of a further inoculation test in laboratory animals in this study, this unique isolate does not allow confirmation of rats as a possible reservoir of ' $B$. rochalimae'. However, several Bartonella species have been shown to use various species of small mammals as their natural reservoirs (Baker, 1946; Birtles et al., 1995; Brenner et al., 1993; Heller et al., 1998; Kordick et al., 1996). Of major importance, several rodent Bartonella species have been shown to be emerging zoonotic pathogens. The first rodent-associated zoonotic Bartonella species was B. elizabethae (Daly et al., 1993), and $R$. norvegicus was considered to be its main reservoir (Ellis et al., 1999). 'B. washoensis' and B. vinsonii subsp. arupensis, which cause human myocarditis and neurological disorders, respectively, were also suggested to be rodent associated (Kosoy et al., 2003; Welch et al., 1999). The present study clearly showed that rodents in Taiwan can harbour Bartonella species, including B. elizabethae, B. tribocorum and a strain closely related to 'B. rochalimae'.

B. clarridgeiae is considered to be an agent possibly causing human cat-scratch disease, with cats being the natural reservoir (Boulouis et al., 2005), and recently 'B. rochalimae', the closest Bartonella species to B. clarridgeiae, was isolated from a human patient (Eremeeva et al., 2007). In a study conducted in northern California, researchers identified a novel B. clarridgeiae-like bacterium from 3 dogs and 22 grey foxes (Henn et al., 2007). These data raise concerns about the existence of other reservoirs and vectors for this emerging infection. For instance, a novel Bartonella species close but distinct from $B$. clarridgeiae was identified in a striped field mouse (Apodemus agrarius) and a yellow-necked field mouse
(Apodemus flavicollis) from Slovenia (Knap et al., 2007). B. clarridgeiae-like bacteria were also detected in rat fleas $(X$. cheopis) collected on brown rats ( $R$. norvegicus) from Egypt (Loftis et al., 2006) and from P. gwyni fleas parasitizing cotton rats (S. hispidus) in the United States (Abbot et al., 2007). Furthermore, according to a phylogenetic analysis of Bartonella species detected in rodent fleas, a genotype designated F15YN, most closely related to B. clarridgeiae, was identified in a Ctenophthalmus lushuiensis flea in China (Li et al., 2007). Because Taiwan is geographically located close to mainland China, the sequence of the gltA gene of the F15YN strain was further compared to the one of our 1-1C strain. After sequence comparison, it showed that a $5 \%$ divergence existed between these two strains. Unfortunately, no sequences for other genes of the F15YN were available for comparison. In this study, we determined that the 1-1C strain was most closely related to ' $B$. rochalimae', on the basis of more than $95 \%$ similarity values for the sequences of $g l t A$, fts $Z$ and $r p o B$ genes, and the 16S-23S rRNA ITS region. Although $95 \%$ similarity for the $g l t A$ gene was also observed between the 1-1C strain and B. clarridgeiae, more divergence was observed by the sequence comparisons of the fts $Z$ and $r p o B$ genes, as well as the 16S-23S rRNA ITS (similarity values: $94.3,93.2$ and $69.1 \%$, respectively). The partial sequence of the 16S-23S rRNA ITS region was shown to be useful to differentiate ' $B$. rochalimae' and B. clarridgeiae. As the phylogenetic analysis showed a specific clade including 'B. rochalimae', B. clarridgeiae and the 1-1C strain, it will be important to further determine the relationship and biological differences of these B. clarridgeiae-like isolates in the future. Although the mode of infection of humans from these rodents is still unclear, ectoparasites might play a role as vectors. Unfortunately, no ectoparasites were collected for detection of Bartonella infection on the bacteraemic rats in our study.

In conclusion, the most significant finding of this study is the identification of a ' $B$. rochalimae'-like organism from $R$. norvegicus, on the basis of sequence and phylogenetic analyses of gltA, fts $Z$ and $r p o B$ genes. Due to the small sample size of animals tested, this study cannot conclude that $R$. norvegicus is the reservoir for ' $B$. rochalimae', but it certainly warrants further investigation.

\section{ACKNOWLEDGEMENTS}

This project was supported by grants $\mathrm{DOH}$ 95-DC1035 from the Department of Health, Taiwan, and NSC 95-2313-B-005-028-MY2 from the National Science Council, Taiwan.

\section{REFERENCES}

Abbot, P., Aviles, A. E., Eller, L. \& Durden, L. A. (2007). Mixed infections, cryptic diversity, and vector-borne pathogens: evidence from Polygenis fleas and Bartonella species. Appl Environ Microbiol 73, 6045-6052.

Baker, J. A. (1946). A rickettsial infection in Canadian voles. J Exp Med 84, 37-50. 
Birtles, R. J., Harrison, T. G., Saunders, N. A. \& Molyneux, D. H. (1995). Proposals to unify the genera Grahamella and Bartonella, with descriptions of Bartonella talpae comb. nov., Bartonella peromysci comb. nov., and three new species, Bartonella grahamii sp. nov., Bartonella taylorii sp. nov., and Bartonella doshiae sp. nov. Int J Syst Bacteriol 45, 1-8.

Boulouis, H.-J., Chang, C. C., Henn, J. B., Kasten, R. W. \& Chomel, B. B. (2005). Factors associated with the rapid emergence of zoonotic Bartonella infections. Vet Res 36, 383-410.

Bown, K. J., Bennett, M. \& Begon, M. (2004). Flea-borne Bartonella grahamii and Bartonella taylorii in bank voles. Emerg Infect Dis $\mathbf{1 0}$ 684-687.

Breitschwerdt, E. B. \& Kordick, D. L. (2000). Bartonella infection in animals: carriership, reservoir potential, pathogenicity, and zoonotic potential for human infection. Clin Microbiol Rev 13, 428-438.

Brenner, D. J., O'Connor, S. P., Winkler, H. H. \& Steigerwalt, A. G. (1993). Proposals to unify the genera Bartonella and Rochalimaea, with descriptions of Bartonella quintana comb. nov., Bartonella vinsonii comb. nov., Bartonella henselae comb. nov., and Bartonella elizabethae comb. nov., and to remove the family Bartonellaceae from the order Rickettsiales. Int J Syst Bacteriol 43, 777-786.

Daly, J. S., Worthington, M. G., Brenner, D. J., Moss, C. W., Hollis, D. G., Weyant, R. S., Steigerwalt, A. G., Weaver, R. E., Daneshvar, M. I. \& O'Connor, S. P. (1993). Rochalimaea elizabethae sp. nov. isolated from a patient with endocarditis. J Clin Microbiol 31, 872-881.

Ellis, B. A., Regnery, R. L., Beati, L., Bacellar, F., Rood, M., Glass, G. G., Marston, E., Ksiazek, T. G., Jones, D. \& Childs, J. E. (1999). Rats of the genus Rattus are reservoir hosts for pathogenic Bartonella species: an Old World origin for a New World disease? J Infect Dis 180, 220-224.

Eremeeva, M. E., Gerns, H. L., Lydy, S. L., Goo, J. S., Ryan, E. T., Mathew, S. S., Ferraro, M. J., Holden, J. M., Nicholson, W. L. \& other authors (2007). Bacteremia, fever, and splenomegaly caused by a newly recognized Bartonella species. N Engl J Med 356, 2381-2387.

Heller, R., Riegel, P., Hansmann, Y., Delacour, G., Bermond, D., Dehio, C., Lamarque, F., Monteil, H., Chomel, B. \& Piémont, Y. (1998). Bartonella tribocorum sp. nov., a new Bartonella species isolated from the blood of wild rats. Int J Syst Bacteriol 48, 1333-1339.

Henn, J. B., Gabriel, M. W., Kasten, R. W., Brown, R. N., Theis, J. H., Foley, J. E. \& Chomel, B. B. (2007). Gray foxes (Urocyon cinereoargenteus) as a potential reservoir of a Bartonella clarridgeiaelike bacterium and domestic dogs as part of a sentinel system for surveillance of zoonotic arthropod-borne pathogens in northern California. J Clin Microbiol 45, 2411-2418.

Jensen, W. A., Fall, M. Z., Rooney, J., Kordick, D. L. \& Breitschwerdt, E. B. (2000). Rapid identification and differentiation of Bartonella species using a single-step PCR assay. J Clin Microbiol 38, 1717-1722.
Kerkhoff, F. T., Bergmans, A. M., van der Zee, A. \& Rothova, A. (1999). Demonstration of Bartonella grahamii DNA in ocular fluids of a patient with neuroretinitis. J Clin Microbiol 37, 4034-4038.

Knap, N., Duh, D., Birtles, R., Trilar, T., Petrovec, M. \& Avšič-Županc, T. (2007). Molecular detection of Bartonella species infecting rodents in Slovenia. FEMS Immunol Med Microbiol 50, 45-50.

Kordick, D. L., Swaminathan, B., Greene, C. E., Wilson, K. H., Whitney, A. M., O'Connor, S., Hollis, D. G., Matar, G. M., Steigerwalt, A. G. \& other authors (1996). Bartonella vinsonii subsp. berkhoffii subsp. nov., isolated from dogs; Bartonella vinsonii subsp. vinsonii; and emended description of Bartonella vinsonii. Int J Syst Bacteriol 46, 704-709.

Kosoy, M., Murray, M., Gilmore, R. D., Jr, Bai, Y. \& Gage, K. L. (2003). Bartonella strains from ground squirrels are identical to Bartonella washoensis isolated from a human patient. J Clin Microbiol 41, 645-650.

Li, D. M., Liu, Q. Y., Yu, D. Z., Zhang, J. Z., Gong, Z. D. \& Song, X. P. (2007). Phylogenetic analysis of Bartonella detected in rodent fleas in Yunnan, China. J Wildl Dis 43, 609-617.

Loftis, A. D., Reeves, W. K., Szumlas, D. E., Abbassy, M. M., Helmy, I. M., Moriarity, J. R. \& Dasch, G. A. (2006). Surveillance of Egyptian fleas for agents of public health significance: Anaplasma, Bartonella, Coxiella, Ehrlichia, Rickettsia, and Yersinia pestis. Am J Trop Med Hyg 75, 41-48.

Marié, J. L., Fournier, P. E., Rolain, J. M., Briolant, S., Davoust, B. \& Raoult, D. (2006). Molecular detection of Bartonella quintana, $B$. elizabethae, B. koehlerae, B. doshiae, B. taylorii, and Rickettsia felis in rodent fleas collected in Kabul, Afghanistan. Am J Trop Med Hyg 74, 436-439.

Norman, A. F., Regnery, R., Jameson, P., Greene, C. \& Krause, D. C. (1995). Differentiation of Bartonella-like isolates at the species level by PCR-restriction fragment length polymorphism in the citrate synthase gene. J Clin Microbiol 33, 1797-1803.

Renesto, P., Gouvernet, J., Drancourt, M., Roux, V. \& Raoult, D. (2001). Use of rpoB gene analysis for detection and identification of Bartonella species. J Clin Microbiol 39, 430-437.

Welch, D. F., Carroll, K. C., Hofmeister, E. K., Persing, D. H., Robison, D. A., Steigerwalt, A. G. \& Brenner, D. J. (1999). Isolation of a new subspecies, Bartonella vinsonii subsp. arupensis, from a cattle rancher: identity with isolates found in conjunction with Borrelia burgdorferi and Babesia microti among naturally infected mice. J Clin Microbiol 37, 2598-2601.

Zeaiter, Z., Liang, Z. \& Raoult, D. (2002). Genetic classification and differentiation of Bartonella species based on comparison of partial ftsZ gene sequences. J Clin Microbiol 40, 3641-3647. 